\title{
Diversity and Abundance of Fish and Invertebrates of Semerak Estuary and Adjacent Inshore Waters, Kelantan.
}

\author{
Chong V.C. ${ }^{1,2 *}$, Jamizan A.R. ${ }^{1}$, Mohamad Yazid Z. ${ }^{1}$, Rizman-Idid M. ${ }^{1,2}$, Muhammad Ali \\ S.H. ${ }^{3}$ and P. Natin ${ }^{4}$
}

${ }^{1}$ Institute Biological Sciences, University of Malaya, 50603 Kuala Lumpur.

${ }^{2}$ Institute of Ocean \& Earth Sciences, University of Malaya, 50603 Kuala Lumpur.

${ }^{3}$ Borneo Marine Research Institute, Universiti Malaysia Sabah, 88999 Kota Kinabalu.

${ }^{4}$ Faculty of Applied Sciences, MARA University of Technology (UiTM), Sabah Branch, 88997 Kota Kinabalu.

*chong@um.edu.my (corresponding author)

Received on $5^{\text {th }}$ August 2009, accepted in revised form $13^{\text {th }}$ October 2009.

\begin{abstract}
Construction of the Tok Bali channel-jetty and channelization of the Semerak River in Bachok had removed and reduced its fringing mangroves, nevertheless, the river modification has improved estuarine circulation. There was invasion of the estuary by at least 59 marine and euryhaline species, including 47 fish species, but prawn and crab fauna were poor. The fish in the estuary included economically-important species of leiognathids, lutjanids, catfishes, barracudas, pomfrets and squids. Bachok's coast provides habitat, feeding and nursery areas to mainly juveniles of 71 fish and 22 invertebrate species. Leiognathids, mullids, cephalopods and portunid crabs were the dominant coastal fishes and invertebrates. The coastal fish fauna including a few reefassociated species was much richer (59 species) to the north of Tok Bali jetty than south of it (16 species). The Leiognathidae with eight species displayed clear spatial distribution from coastal to estuarine waters.
\end{abstract}

\begin{abstract}
ABSTRAK Pembinaan terusan-jeti Tok Bali dan pelurusan Sungai Semerak di Bachok telah mengakibatkan kehilangan hutan bakau tebing sungai di kawasan sekitarnya. Walaupun bagaimanapun, pengubahsuaian sungai ini telah memperbaiki peredaran air di muara. Terdapat invasi kawasan muara oleh sekurang-kurangnya 59 spesis eurihalin, termasuk 47 spesis ikan, namun demikian bilangan fauna ketam dan udang adalah rendah. Spesies ikan yang ditemui di muara termasuklah spesis yang penting dari segi ekonomi seperti leiognatid (kekek), lutjanid (jenahak), catfish (ikan duri), barracuda (alu-alu), bawal dan sotong. Pesisiran Bachok menyediakan habitat, serta kawasan nurseri dan pemakanan bagi 71 spesies ikan juvenil dan 22 spesis invertebrata. Leiognathid (kekek), mullid (belanak), sotong dan ketam portunid merupakan ikan dan invertebrata pesisir yang utama. Kepelbagaian fauna ikan, termasuk beberapa spesis yang berkait dengan terumbu karang adalah lebih tinggi (59 spesies) di utara Tok Bali berbanding bahagian selatan. Spesis ikan kekek menunjukkan taburan spatial yang jelas dari pesisir ke muara sungai.
\end{abstract}

(Keywords: fish and invertebrates, mangroves, inshore waters, Semerak River, Bachok coast, Kelantan)

\section{INTRODUCTION}

Linkages between mangroves and fisheries have been well documented in Malaysia [1] and throughout the world [e.g. 2, 3, 4, 5]. In peninsular Malaysia, most mangrove fish and invertebrate studies have mainly focused on its west coast where mangroves are the dominant coastal habitats, e.g. Langkawi $[7,8]$ and Merbok [9, 10] in Kedah; Dinding [11] and Matang $[12,13,14,15,16]$ in Perak; Klang [17, 18, 19, 20] and Kuala Selangor [21] in Selangor; and Sungai Pulai and Sungai Johor in Johor [22]. Excluding Johor, the east coast of the peninsula has a total of only 3,711 ha of mangrove reserves with 3,286 ha of stateland forest as opposed to respectively 65,195 ha and 7,042 ha on the west coast [23]. Most of Johor's reserved and stateland mangroves $(17,185+3,348$ ha) are located on the southern end of the peninsula. The state of Kelantan located at the northeastern region of peninsular Malaysia has no mangrove reserve but stateland mangrove forests of 744 ha [23] are found inside the various estuaries including that of the Semerak river.

Kelantan's annual fisheries catch amounted to 46,494 tonnes in 2005 [24]. It may be stated that mangroves will have little influence on Kelantan's coastal fisheries which appear to depend heavily on pelagic fish. Nevertheless, as in the case of northern Pahang, sheltered coastal bays, lagoons and estuaries may be important nursery or feeding areas for demersal fishes including spawning grounds for squids and cuttlefish [25]. 
The objective of this study was to determine the diversity and abundance of the Semerak estuary and adjacent nearshore waters along Bachok's coast in Kelantan. This study formed part of an expedition to Bachok, organized by the Institute of Ocean \& Earth Sciences (IOES), University of Malaya (UM), from 14-20 June 2008. The main purpose of this expedition was to discover and inventorize the biodiversity of Kelantan's coastal environment, particular that of the district of Bachok where the IOES has recently set up its marine station (UMBMS) at Kuala Rekang.

\section{MATERIALS AND METHODS}

\section{Study area}

From its headwaters near $\mathrm{Kg}$. Gong Jelor $\left(5^{\circ} 52.5^{\prime} \mathrm{N}\right.$, $\left.102^{\circ} 23.5^{\prime} \mathrm{E}\right)$, the Semerak River meanders its way along the southern borders of Pasir Putih and Bachok districts down to the Kelantan coastline. The river drains through patchy secondary lowland forests and swamps, as well as supplying irrigation water to padi fields and coconut plantations. Extensive sand spits and dunes have almost closed the original entrance of the estuary, thus creating a shallow lagoon at the river mouth. This lagoon is heavily used for floating fish cage, pen and pond culture.

Estuarine flushing of the river is now maintained through the construction of a $1 \mathrm{~km}-$ long by $0.3 \mathrm{~km}$ wide dug-through channel from the river at Tok Bali, across the coastal strip to the sea. The channel continues upstream along a straight path from Tok Bali jetty to about $7.5 \mathrm{~km}$ upstream where a tidal barrage $\left(\mathrm{N} 5^{\circ} 50.9^{\prime}, \mathrm{E} 102^{\circ} 26.3^{\prime}\right)$ impounds the river water upstream of it (Figure 1). The barrage thus marks the upper limit of the altered Semerak estuary. The channelization process cuts off the natural meandering section of the Semerak River from $\mathrm{Kg}$. Hutan Beris to Gong Tok Yah. The upper channel from the latter to the barrage has a width of $0.15 \mathrm{~km}$. The deep and wide Tok Bali channel with its extended jetties allows the passage of large boats.

The entire Bachok coastline is lined by a narrow sandy beach backed by mainly coconut plantations. Mangrove forest patches are found around the Semerak lagoon, extending upstream to near Tok Bali jetty where the best patches are found just south of it. The river channelization process had removed most of the mangroves along it, with only patchy narrow fringes or remnants surviving along the river up to the tidal barrage. Twenty-one sampling stations were established in the Semerak and Rekang estuary and adjacent coastal waters of Bachok. Their GPS positions (Table 1) were recorded using a GARMIN
Rhino 130. Stations 1-5 were located on the northern section of the coast from Tok Bali jetty, varying from 0.5 - $3 \mathrm{~km}$, off Kuala Rekang (stations 1,2) off Kuala Kandis (station 3 ) and off $\mathrm{Kg}$. Tok Kedarat (stations 4) and off Kg. Pak Ya'akob (5) (Figure 1). Water depths varied from $4-7 \mathrm{~m}$. In the southern coastal section, the four stations were located off Tok Bali jetty (station 6), off $\mathrm{Kg}$. Tok Bali (station 7), off $\mathrm{Kg}$. Kuala Semarak (station 8) and off Kg. Dalam Ru (station 9), the latter located about $3 \mathrm{~km}$ from the state border between Kelantan and Terengganu.

Sampling stations within the Semerak estuary in water depths varying between 4-6m included five stations from Kampong Mak Yong (station 10) upstream to the tidal barrage (station 14); the sixth station near Kg. Ketik Buloh (station 15) was the farthest downstream. Samplings were also conducted at Semerak lagoon (stations 16-19, 4m depth). Rekang estuary (station 20,1.5m) and the surf zone (station 21,1.2m) near its mouth were the northern most stations sampled. At the time of sampling, the small Rekang river in the dry season did not flow out to the sea. Shifting berms or sand dunes which characterized the east coast often blocked off the access of small rivers. The Rekang sites, near to the IOES marine station, were however not the main focus of the present study.

\section{Sampling methods}

The main fish sampling gear used was a commercial otter trawl with a head rope length of $16 \mathrm{~m}$ and codend stretched mesh size of $2 \mathrm{~cm}$. At sampling station, the trawl net was deployed and fished for variable durations of 10-30 min during day time (Table 1). Longer trawling time was taken at coastal stations to cover a longer trawl over distance, whereas in the estuary shorter times were taken because adjacent stations were closer to each other. The ground speed of the boat during fishing was estimated by the chip board cast method and validated by GPS.

Since the trawl boat could not approach the lagoon due to the bridge across the river at $\mathrm{Kg}$. Cherang Ruku, the sampling methods adopted at Semerak lagoon were the use of a gill net, 3-layered trammel net and beam trawl. The gill and trammel nets measured $180 \times 3 \mathrm{~m}$ and $90 \times 2 \mathrm{~m}(\mathrm{~L} \times \mathrm{D})$ with mesh sizes of 2.5 " and 6"-1.75"-6" respectively. The beam trawl had a fixed width of $2 \mathrm{~m}$ and codend mesh size of 0.5 ". A cast net and beach seine were used at the small Rekang river and the beach fronting UMBMS, respectively. 


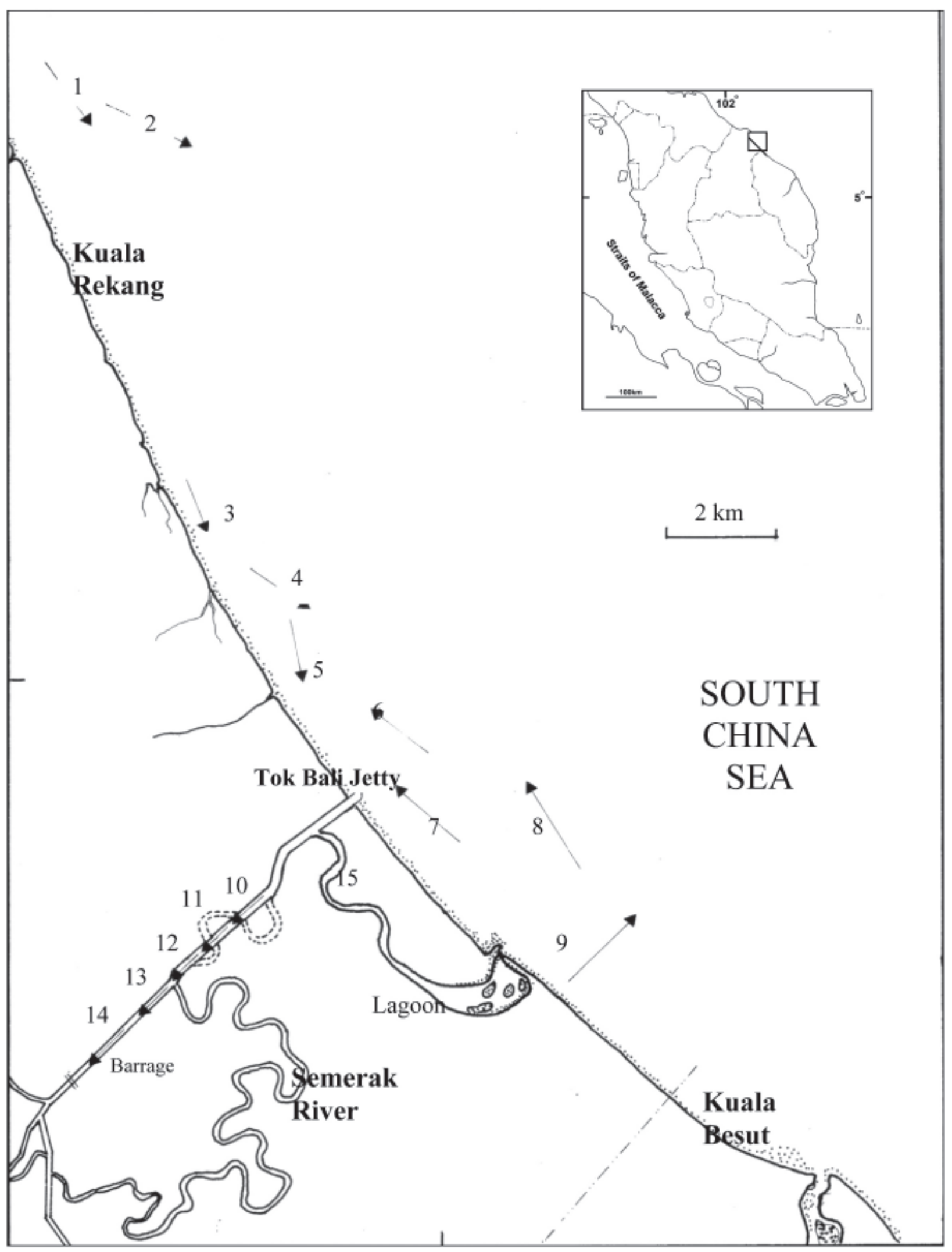

Figure 1. Map showing trawling stations $(1-15)$ along Semerak River and coastal waters of Bachok, Kelantan. Arrow head indicates end of trawl. Inset shows study area (boxed) in Kelantan, peninsula Malaysia. 
Table 1. Sampling information of Bachok (Kelantan) coastal fish and invertebrate study.

\begin{tabular}{lcccccccc}
\hline Location & Date & Station & Sample & $\begin{array}{c}\text { Start * } \\
\text { Longitude }\end{array}$ & Latitude & $\begin{array}{c}\text { End* } \\
\text { Longitude }\end{array}$ & $\begin{array}{c}\text { Latitude } \\
\text { Depth } \\
\text { (m) }\end{array}$ \\
\hline Northern & 16-Jun-08 & 1 & $\mathrm{~N} 1$ & 102.42785 & 6.03517 & 102.43388 & 6.02636 & \\
Coast & 16-Jun-08 & 2 & $\mathrm{~N} 2$ & 102.42963 & 6.03318 & 102.44990 & 6.02374 & \\
& 16-Jun-08 & 3 & $\mathrm{~N} 3$ & 102.45570 & 5.95133 & 102.45765 & 5.94562 & 5.0 \\
& 16-Jun-08 & 4 & $\mathrm{~N} 4$ & 102.47267 & 5.93714 & 102.47691 & 5.92926 & 6.6 \\
& 16-Jun-08 & 5 & $\mathrm{~N} 5$ & 102.47079 & 5.92522 & 102.47402 & 5.91734 & 4.4 \\
Southern & 15-Jun-08 & 6 & $\mathrm{~S} 4$ & 102.49717 & 5.91232 & 102.48631 & 5.91855 & \\
Coast & 15-Jun-08 & 7 & $\mathrm{~S} 1$ & 102.49157 & 5.90110 & 102.50424 & 5.88935 & \\
& 15-Jun-08 & 8 & $\mathrm{~S} 2$ & 102.50745 & 5.89303 & 102.52170 & 5.88319 & \\
& 15-Jun-08 & 9 & $\mathrm{~S} 3$ & 102.52299 & 5.85526 & 102.53502 & 5.87294 & \\
Estuary & 17-Jun-08 & 15 & $\mathrm{R} 6$ & 102.48162 & 5.88500 & 102.47845 & 5.88096 & 4.2 \\
& 17-Jun-08 & 10 & $\mathrm{R} 1$ & 102.46888 & 5.87863 & 102.46297 & 5.87593 & 4.4 \\
& 17-Jun-08 & 11 & $\mathrm{R} 2$ & 102.46291 & 5.87573 & 102.45727 & 5.87101 & 5.3 \\
& 17-Jun-08 & 12 & $\mathrm{R} 3$ & 102.45891 & 5.87248 & 102.45461 & 5.86796 & 4.1 \\
& 17-Jun-08 & 13 & $\mathrm{R} 4$ & 102.45573 & 5.86603 & 102.44837 & 5.86097 & 5.8 \\
& 17-Jun-08 & 14 & $\mathrm{R} 5$ & 102.44599 & 5.85811 & 102.44144 & 5.85284 & 6.1 \\
$\begin{array}{l}\text { Sg. Rekang } \\
\text { (surf zone) }\end{array}$ & 18-Jun-08 & 21 & $\mathrm{~B} 1, \mathrm{~B} 2$ & 102.42735 & 6.00722 & & & $1-2$ \\
$\begin{array}{l}\text { Semerak } \\
\text { Lagoon }\end{array}$ & & & & & & & & \\
\hline
\end{tabular}

* Start and End indicate start and end GPS positions of otter trawl hauls (N1-N5, S1-S4, and R1-R6).

All fish and invertebrate catches were taken whole, but subsampled if the catch was too large. Only the Leiognathidae were sub-sampled because their catches were superfluous at some stations. Fish samples were immediately chilled in ice kept inside a Coleman ice-chest.

Water parameters were measured in-situ by an YSI 556MPS meter, which included salinity (ppt), conductivity $(\mathrm{mS} \mathrm{cm}-1)$, temperature $\left({ }^{\circ} \mathrm{C}\right), \mathrm{pH}$ and dissolved oxygen $\left(\mathrm{mg} \mathrm{l}^{-1}\right)$. Water depth $(\mathrm{m})$ at station was measured by a Speedtech M5 hand-held echosounder.

At base camp, all fish and invertebrates were immediately identified to the species level using relevant taxonomic keys [26, 27, 28, 29, 30, 31]. Difficult species were tagged and preserved in $10 \%$ formaldehyde kept in lidded, 5-gallon plastic tubs. After identification, all specimens of the same species were counted and weighed together. Minimum and maximum standard lengths (SL) were measured. Unidentified species were photographed with high resolution digital camera, and brought back to UM's laboratory for further identification and confirmation. The valid fish species name as given in Fishbase [32] was adopted.

\section{Quantification}

The following diversity indices with their usual notations were computed for the estuarine and coastal fish and invertebrate communities (except the Rekang sites) Margalef's species richness $\left(D_{a}\right)=(s-$ 1) $/ \log _{\mathrm{e}} \mathrm{N}$; Shannon-Weiner's diversity index $\left(\mathrm{H}^{\prime}\right)=$ $\sum \mathrm{p}_{\mathrm{i}} \log _{\mathrm{e}} \mathrm{p}_{\mathrm{i}}$; Maximum diversity $\left(\mathrm{H}^{\prime}{ }_{\max }\right)=\log _{\mathrm{e}} \mathrm{s}$, and Pielou's evenness index $\left(\mathrm{J}^{\prime}\right)=\mathrm{H}^{\prime} / \mathrm{H}^{\prime}{ }_{\max }$, where $\mathrm{s}=$ number (no.) of species, $\mathrm{N}=$ total number of specimens and $\mathrm{p}_{\mathrm{i}}=$ proportion of the $\mathrm{i}^{\text {th }}$ species.

Fish density (no. ha $\left.{ }^{-1}\right)$ and biomass $\left(\mathrm{kg} \mathrm{ha}^{-1}\right)$ were computed using the swept area method with a fish retention ratio of 0.5 as recommended for tropical trawl surveys [33]. The method also recommends calculation of the swept area width as half the headrope length, i.e. in the present case, $8 \mathrm{~m}$.

The fish and invertebrate lists of the estuary and coastal waters were compared by computing Jaccard's coefficient of community, given by $S=a / j$, where $a=$ no. of species in common, $j=$ total no. of species excluding species absent in both communities. 
Table 2. Water parameters measured at Semerak Estuary and Bachok's coastal waters (15-19 June 2008).

\begin{tabular}{|c|c|c|c|c|c|c|c|c|c|c|c|}
\hline Location & Station & Date & Time & $\begin{array}{c}\text { Depth } \\
\text { layer }\end{array}$ & $\begin{array}{c}\text { Temp } \\
\left({ }^{\circ} \mathrm{C}\right) \\
\end{array}$ & $\begin{array}{c}\text { Cond } \\
(\mathrm{mS} / \mathrm{cm})\end{array}$ & $\begin{array}{l}\text { TDS } \\
(\mathrm{g} / \mathrm{L}) \\
\end{array}$ & $\begin{array}{c}\text { Sal } \\
\text { (ppt) }\end{array}$ & $\begin{array}{c}\text { DOsat } \\
(\%) \\
\end{array}$ & $\begin{array}{c}\text { DO } \\
(\mathrm{mg} / \mathrm{L})\end{array}$ & pH \\
\hline \multirow[t]{20}{*}{ Northern Coast } & \multirow[t]{2}{*}{1} & 16-Jun & $10: 51$ & surface & 30.93 & 56.88 & 33.21 & 33.37 & 80.47 & 4.99 & 7.91 \\
\hline & & 16-Jun & $10: 51$ & surface & 0.11 & 0.03 & 0.06 & 0.06 & 1.16 & 0.08 & 0.13 \\
\hline & \multirow[t]{2}{*}{2} & 16-Jun & $11: 58$ & surface & 31.33 & 57.12 & 33.12 & 33.25 & 81.30 & 5.01 & 8.06 \\
\hline & & 16-Jun & $11: 58$ & surface & 0.30 & 0.25 & 0.03 & 0.04 & 0.62 & 0.06 & 0.00 \\
\hline & \multirow[t]{2}{*}{2} & 16-Jun & $11: 59$ & bottom & 31.08 & 56.88 & 33.12 & 33.26 & 81.33 & 5.03 & 8.07 \\
\hline & & 16-Jun & $11: 59$ & bottom & 0.36 & 0.28 & 0.04 & 0.06 & 0.82 & 0.08 & 0.01 \\
\hline & \multirow[t]{2}{*}{3} & 16-Jun & $13: 11$ & surface & 31.58 & 57.58 & 33.24 & 33.38 & 84.40 & 5.18 & 8.05 \\
\hline & & 16-Jun & $13: 11$ & surface & 0.02 & 0.01 & 0.01 & 0.01 & 0.10 & 0.01 & 0.03 \\
\hline & \multirow[t]{2}{*}{3} & 16-Jun & $13: 11$ & bottom & 31.57 & 57.55 & 33.24 & 33.37 & 84.53 & 5.19 & 8.09 \\
\hline & & 16-Jun & $13: 11$ & bottom & 0.00 & 0.01 & 0.00 & 0.00 & 0.12 & 0.01 & 0.00 \\
\hline & \multirow[t]{2}{*}{4} & 16-Jun & $14: 19$ & surface & 30.84 & 55.36 & 32.37 & 32.42 & 88.43 & 5.52 & 7.71 \\
\hline & & 16-Jun & $14: 19$ & surface & 0.55 & 0.02 & 0.30 & 0.36 & 0.32 & 0.02 & 0.14 \\
\hline & \multirow[t]{2}{*}{4} & 16-Jun & $14: 19$ & bottom & 31.22 & 56.77 & 32.99 & 33.11 & 89.67 & 5.54 & 8.03 \\
\hline & & 16-Jun & $14: 19$ & bottom & 0.17 & 0.27 & 0.26 & 0.29 & 0.12 & 0.01 & 0.03 \\
\hline & \multirow[t]{2}{*}{5} & 16-Jun & $15: 01$ & surface & 31.74 & 49.68 & 28.61 & 28.21 & 131.57 & 8.30 & 8.07 \\
\hline & & 16-Jun & $15: 01$ & surface & 0.49 & 0.88 & 0.38 & 0.41 & 55.29 & 3.57 & 0.14 \\
\hline & \multirow[t]{2}{*}{5} & 16-Jun & $15: 01$ & bottom & 31.54 & 55.98 & 32.35 & 32.37 & 96.53 & 5.96 & 8.13 \\
\hline & & 16-Jun & $15: 01$ & bottom & 0.17 & 1.06 & 0.70 & 0.80 & 1.36 & 0.10 & 0.01 \\
\hline & \multirow[t]{2}{*}{5} & 16-Jun & $15: 27$ & surface & 32.37 & 34.19 & 19.48 & 18.40 & 96.48 & 6.34 & 8.03 \\
\hline & & 16-Jun & $15: 27$ & surface & 0.02 & 0.14 & 0.08 & 0.09 & 0.33 & 0.02 & 0.01 \\
\hline \multirow[t]{8}{*}{ Southern Coast } & \multirow[t]{2}{*}{6} & 15-Jun & $15: 35$ & surface & 32.22 & 52.37 & 29.95 & 29.63 & 88.43 & 5.49 & 7.17 \\
\hline & & 15-Jun & $15: 35$ & surface & 0.07 & 0.23 & 0.11 & 0.18 & 0.32 & 0.02 & 0.82 \\
\hline & \multirow[t]{2}{*}{7} & 15-Jun & $12: 03$ & surface & 31.28 & 57.60 & 33.43 & 33.60 & 89.13 & 5.49 & 7.72 \\
\hline & & 15-Jun & $12: 03$ & surface & 0.01 & 0.01 & 0.00 & 0.00 & 0.21 & 0.01 & 0.33 \\
\hline & \multirow[t]{2}{*}{8} & 15-Jun & $13: 08$ & surface & 31.54 & 57.79 & 33.40 & 33.55 & 87.10 & 5.34 & 7.95 \\
\hline & & 15-Jun & $13: 08$ & surface & 0.07 & 0.02 & 0.05 & 0.05 & 0.10 & 0.01 & 0.16 \\
\hline & \multirow[t]{2}{*}{9} & 15-Jun & $14: 06$ & surface & 32.03 & 57.89 & 33.18 & 33.29 & 85.17 & 5.20 & 8.00 \\
\hline & & 15-Jun & $14: 06$ & surface & 0.03 & 0.12 & 0.08 & 0.10 & 0.68 & 0.04 & 0.03 \\
\hline \multirow[t]{10}{*}{ Semerak River } & \multirow[t]{2}{*}{10} & 17-Jun & 9:59 & surface & 30.94 & 32.55 & 20.78 & 19.99 & 64.37 & 4.28 & 7.40 \\
\hline & & 17-Jun & 9:59 & surface & 0.44 & 18.46 & 9.54 & 10.10 & 8.91 & 0.46 & 0.49 \\
\hline & \multirow[t]{2}{*}{11} & 17-Jun & $10: 29$ & surface & 31.27 & 32.46 & 22.74 & 21.95 & 60.70 & 3.96 & 7.51 \\
\hline & & 17-Jun & $10: 29$ & surface & 0.01 & 0.17 & 6.65 & 7.15 & 11.61 & 0.58 & 0.38 \\
\hline & \multirow[t]{2}{*}{11} & 17-Jun & $10: 29$ & bottom & 31.45 & 52.72 & 30.54 & 30.35 & 74.27 & 4.64 & 7.97 \\
\hline & & 17-Jun & $10: 29$ & bottom & 0.01 & 0.18 & 0.07 & 0.08 & 0.12 & 0.01 & 0.01 \\
\hline & \multirow[t]{2}{*}{12} & 17-Jun & $11: 07$ & surface & 31.43 & 27.00 & 15.63 & 14.46 & 54.30 & 4.02 & 7.50 \\
\hline & & 17-Jun & $11: 07$ & surface & 0.02 & 0.57 & 0.33 & 0.33 & 0.10 & 0.55 & 0.42 \\
\hline & \multirow[t]{2}{*}{12} & 17-Jun & $11: 07$ & bottom & 31.49 & 53.34 & 30.84 & 30.69 & 72.90 & 4.26 & 7.64 \\
\hline & & 17-Jun & $11: 07$ & bottom & 0.03 & 0.79 & 0.48 & 0.53 & 0.36 & 0.48 & 0.33 \\
\hline
\end{tabular}




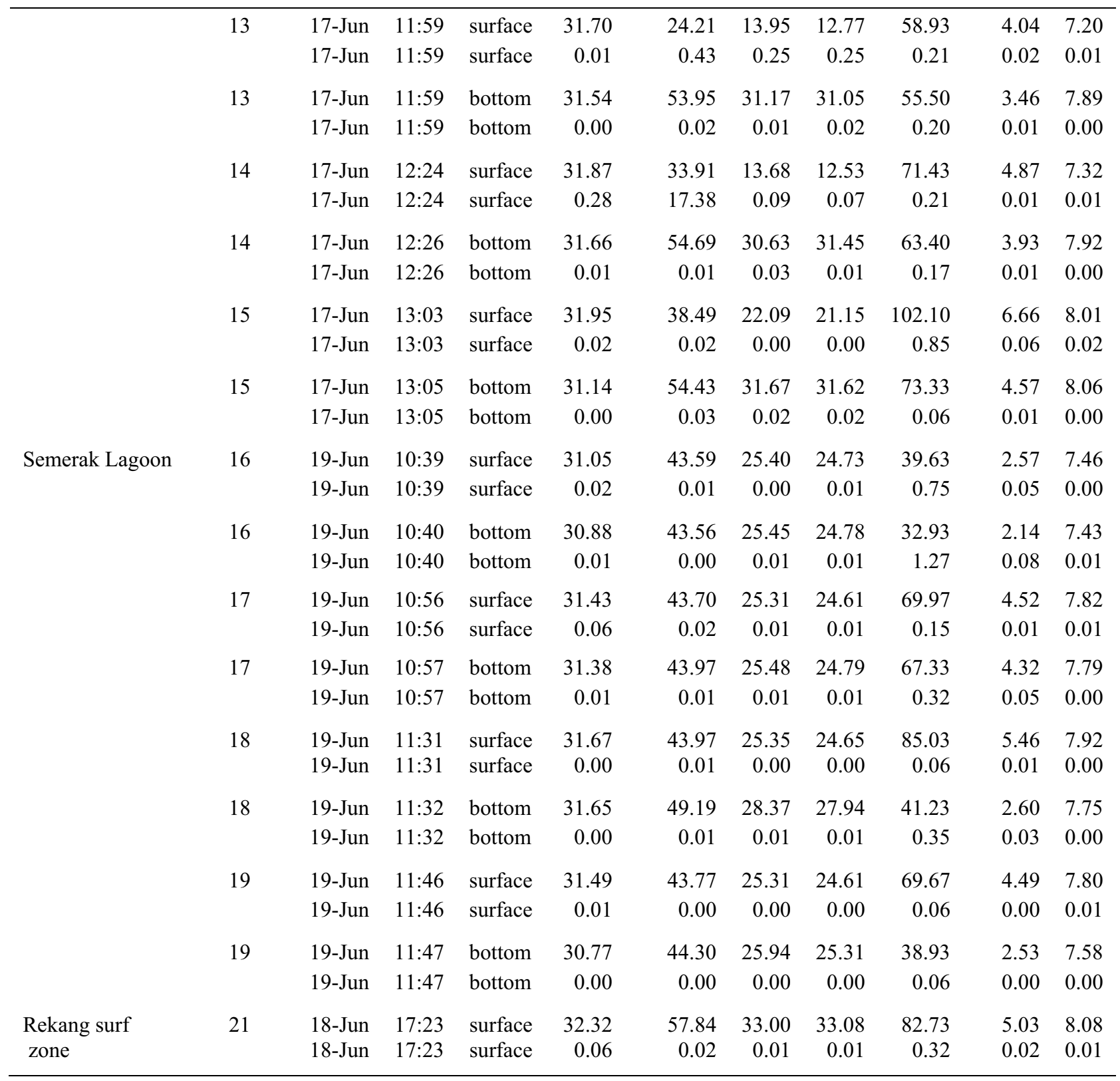

Temp $=$ temperature, Cond $=$ conductivity, TDD $=$ total dissolved solids, Sal $=$ salinity, DOsat $=$ dissolved oxygen $(\%$ saturation $) ; \mathrm{DO}=$ dissolved oxygen $(\mathrm{mg} / \mathrm{L})$. For each station, first row indicates mean, second row indicates standard deviation $(\mathrm{n}=3)$.

\section{RESULTS AND DISCUSSION}

\section{Water parameters}

Mean ( \pm SE) surface and bottom temperature, conductivity, total dissolved solids, salinity, dissolved oxygen and $\mathrm{pH}$ values recorded at the various locations and stations are given in Table 2. At Semerak estuary, the mean surface salinity increased from $12.53 \mathrm{ppt}$ (Station 14) near the tidal barrage to 21.15 ppt near to Kg. Ketik Buloh (Station 15) on the downstream. Further downstream at Semarak lagoon (river mouth), mean salinity varied little between
$24.61 \mathrm{ppt}$ to $24.73 \mathrm{ppt}$. Mean bottom salinity readings were high and consistent from upstream to downstream, ranging from $30.05 \mathrm{ppt}$ to $31.62 \mathrm{ppt}$, indicating a partially-mixed estuary to a well-mixed one, e.g. Semerak lagoon. Mean surface TDS (13.68 - $\left.21.15 \mathrm{mS} \mathrm{cm}^{-1}\right)$ and $\mathrm{pH}(7.32$ - 8.01) followed the same trend as salinity, increasing from upstream to lagoon. Mean surface temperature remained consistent at about $31-32^{\circ} \mathrm{C}$, while mean surface dissolved oxygen ranged between $4-7 \mathrm{mg} \mathrm{l}^{-1}$, with sufficient oxygenation at the bottom for most marine life (not less than $3.5 \mathrm{mg} \mathrm{l}^{-1}$ ). 
Coastal waters away from river mouths had high surface salinities that exceeded 33 ppt. Near to the Tok Bali jetty entrance, the mean salinities recorded at two occasions were $28.21 \mathrm{ppt}$ and $29.63 \mathrm{ppt}$. Sea surface temperatures ranged from $30.84 \mathrm{ppt}$ to 32.03 ppt, while DO and $\mathrm{pH}$ levels were generally higher than in the estuary or lagoon.

There is no published record of the estuarine circulation in Semerak River prior to channelization and construction of the Tok Bali jetty, but its sinuous morphology suggests a weak, slow flowing river with little tidal exchanges due to massive sand blockage at its mouth. Construction of the by-pass (deep channel) and jetty at Tok Bali appears to have improved its estuarine circulation at present.

\section{Species diversity, composition and abundance Community indices}

The various indices for the fish and invertebrate communities of Semerak estuary and adjacent coastal waters are tabulated in Table 3. A total of 47 fish and 12 invertebrate species were sampled from Semerak estuary (and lagoon), while in the near coastal waters there were 71 and 22 species respectively.

Table 3. Community indices of Bachok's coastal water and Semerak Estuary.

\begin{tabular}{lccccc}
\hline INDEX * $^{*}$ & $\mathbf{S}$ & $\mathbf{D}$ & $\mathbf{H}^{\prime}$ & $\mathbf{J}^{\prime}$ & $\mathbf{H}_{\text {max }}$ \\
\hline COAST & & & & & \\
Whole Community & 93 & 10.92 & 3.12 & 0.69 & 4.53 \\
Fish & 71 & 8.31 & 2.80 & 0.66 & 4.26 \\
Invertebrate & 22 & 3.10 & 1.90 & 0.62 & 3.09 \\
ESTUARY & & & & & \\
Whole Community & 58 & 7.61 & 2.20 & 0.54 & 4.06 \\
Fish & 47 & 6.15 & 2.14 & 0.56 & 3.85 \\
Invertebrate & 12 & 3.61 & 2.03 & 0.82 & 2.48 \\
\hline
\end{tabular}

$\mathrm{S}=$ number of species, $\mathrm{D}_{\mathrm{a}}=$ Margalef species richness, $\mathrm{H}^{\prime}=$ Shannon-Weiner diversity index, $\mathrm{J}^{\prime}=$ Pielou's evenness, $\mathrm{H}_{\max }^{\prime}=$ maximum diversity.

The species numbers and diversity indices $\left(\mathrm{H}^{\prime}, \mathrm{H}^{\prime}\right.$ $\max )$ for fish in Semerak estuary $(s=47, D=6.15$, $\mathrm{H}^{\prime}=2.14, \mathrm{H}_{\text {max }}=3.85$ ) were low and comparable to the Dinding estuary $(49,2.87,3.89)$ of Perak, where a similar situation of degraded mangroves occurs [22]. The low diversity is attributed to the presence of high numbers of certain dominant families (see below) as evident from the low evenness value (0.56). Relatively undisturbed mangrove swamps of Matang (Perak) had corresponding higher values of $89,7.58$, 3.66 and 4.47 respectively.

The coastal fish community indices $(\mathrm{s}=71, \mathrm{D}=8.31$, $\mathrm{H}^{\prime}=2.80, \mathrm{H}^{\prime}{ }_{\text {max }}=4.26$ ) of Bachok had comparable or higher values than that of northern Pahang's richest coastal waters at Chendur $(47,7.32,2.52,3.85)$ [25] and Klang coastal waters $(58,7.71,2.78,4.06)$ [19].

Macroinvertebrate species richness and diversity were low for both estuarine $(3.61,2.03)$ and coastal waters $(3.1,1.9)$. These values were about similar to the highest obtained from the coastal waters off the mouth of the Kuantan River to Tanjung Pelindung $(3.2,1.9)[25]$.

\section{Semerak estuary}

At the lower reaches of the river (station 15) just before it opens into the enclosed lagoon at Kuala Semerak, the highest number of species (31) were sampled. The fish comprised of 24 species which were dominated by the Leiognathidae, commonly called ponyfishes or ikan kekek $\left(>2,000\right.$ indiv. $\mathrm{ha}^{-1}$; $80 \%$ of total). The mainly juvenile fish $(2-13.5 \mathrm{~cm}$ $\mathrm{SL})$ were five species ranked as follows: Secutor ruconius, Leiognathus brevirostris, L. splendens, $L$. equulas and Gazza minuta (Table 4, Figure 2). Highly valuable commercial fish included the Chinese pomfret (Pampus chinensis, 13.7-15.1 cm), silver pomfret (P.argenteus, $14.6 \mathrm{~cm})$, largetooth flounder (Pseudorhombus arsius) and the mangrove snapper (Lutjanus johnii, $15.5-10 \mathrm{~cm}$ ). A rare find is the highly venomous stonefish, Leptosynanceia asteroblepa (Figure 3). Seven species of juvenile invertebrates were sampled, which included starfish (Astropecten vappa), crabs (Portunus pelagicus, Charybdis japonica, Thalamita crenata and Doriipidae), squids (Loligo sp.) and prawns (Metapenaeus lysianassa and M. mastersii).

In the channelized part of the river at $\mathrm{Kg}$. Pak Mayong (Station 10), 13 species of fish with no invertebrates were sampled. As in the lower station, the fish community comprised of mainly species of the Leiognathidae ( $>1000$ indiv. ha $^{-1}$ ), constituted by mainly juveniles $(2-8.2 \mathrm{~cm} \mathrm{SL})$ of the above stated species. Other abundant fish included the estuarine pufferfish (Tetraodon fluviatilis) and catfishes (Arius 


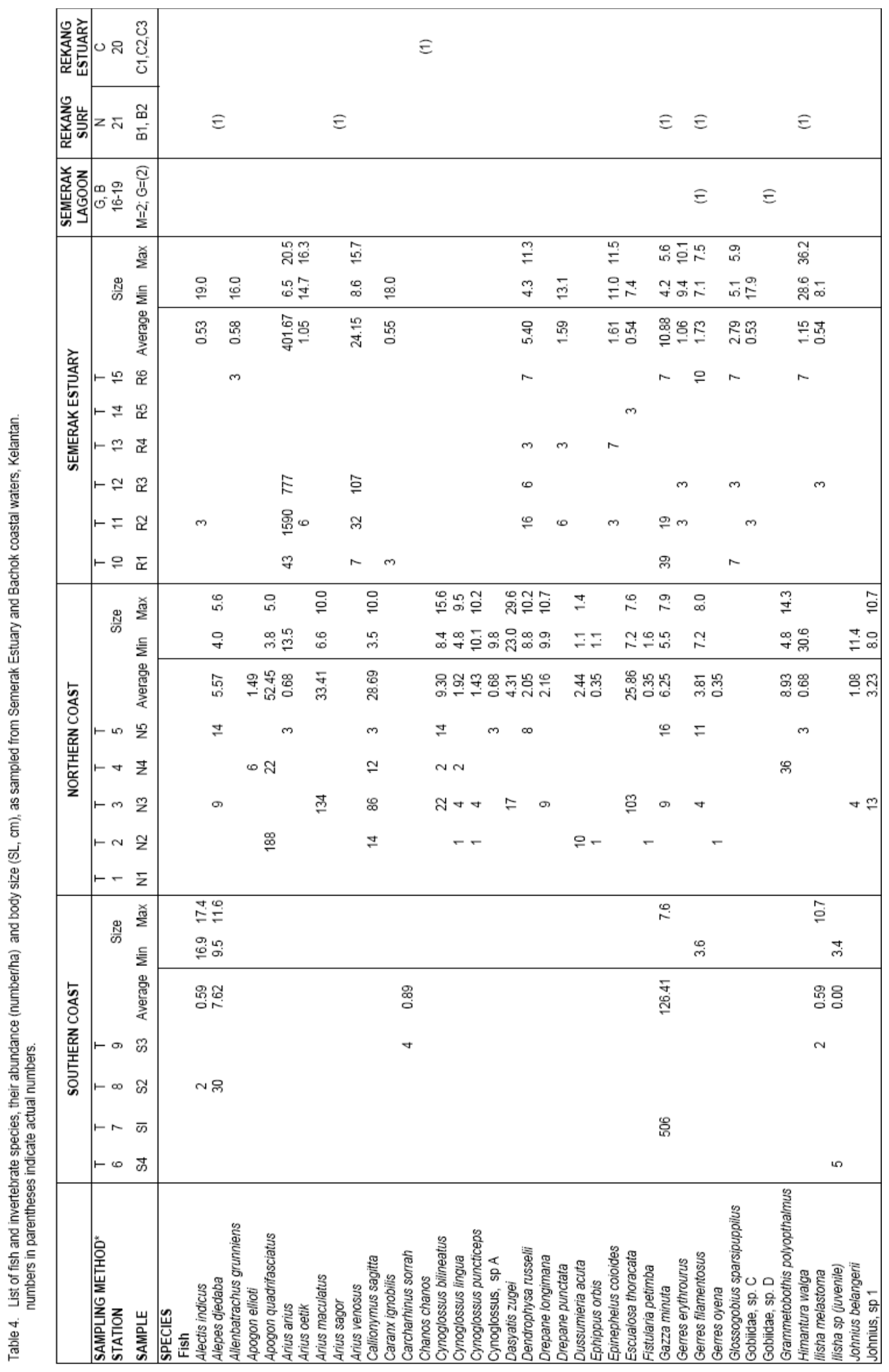




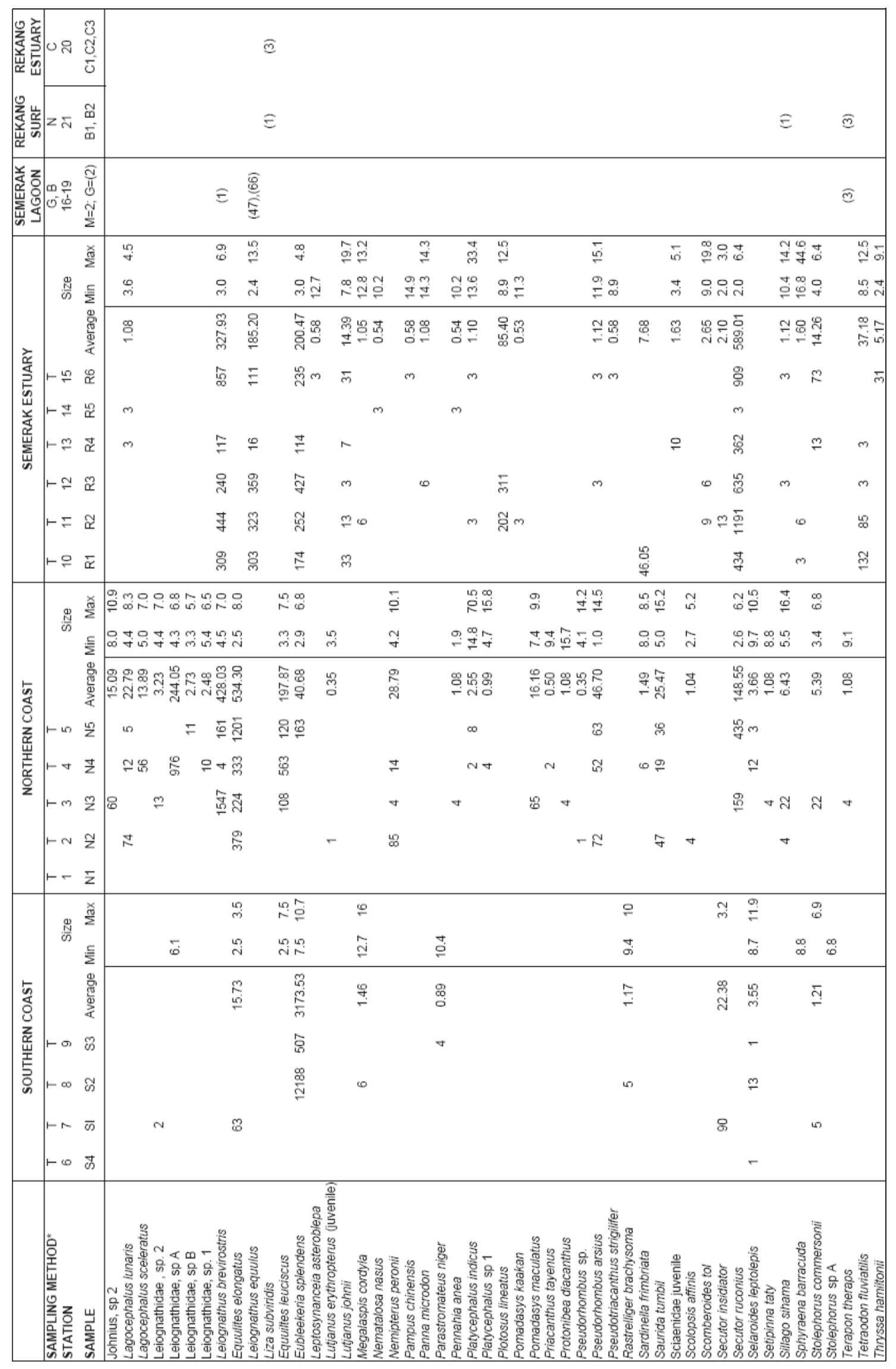




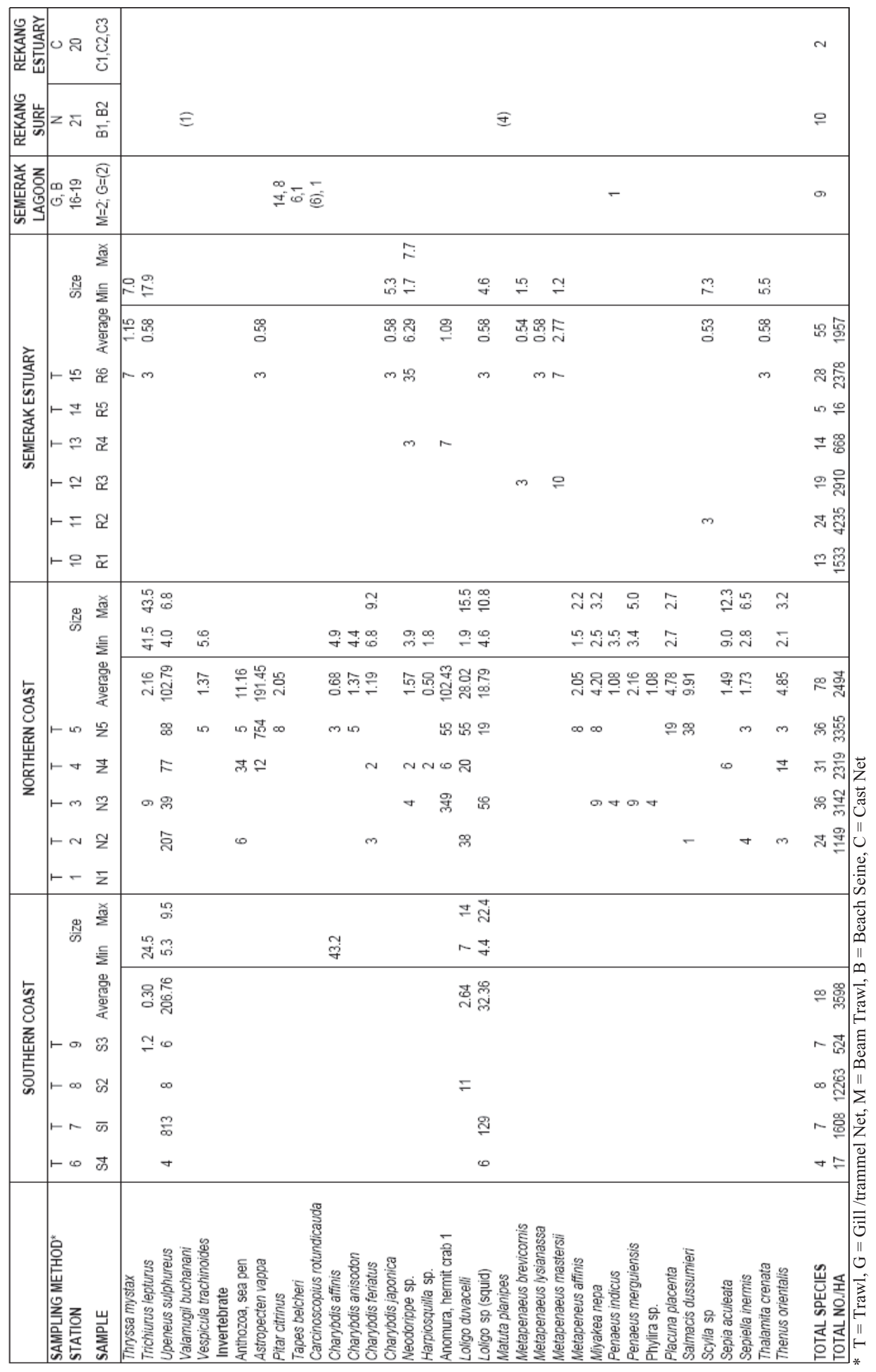




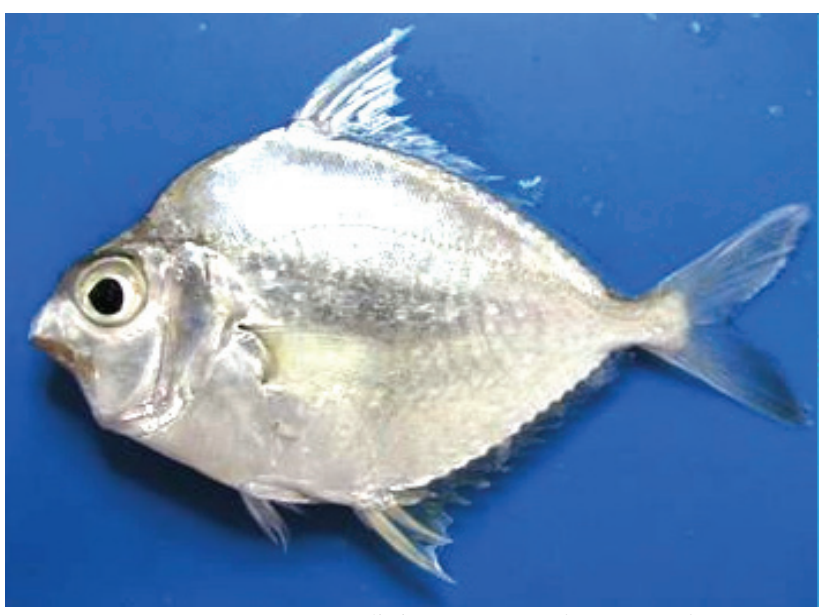

Figure 2. Common ponyfish, Leiognathus equula $(6.5 \mathrm{~cm} \mathrm{SL})$

venosus, $A$. arius). Highly valuable commercial fish included the juveniles of the mangrove snapper (Lutjanus johnii, 7.8-19.7cm), giant trevally (Caranx ignobilis, $18 \mathrm{~cm}$ ) and reef barracuda (Sphyraena barracuda, $16.8-44.6 \mathrm{~cm})$.

Proceeding from Station 10 to stations further upstream, the number of fish species recorded was $25,19,14$ and 5 at stations 11, 12, 13 and 14, respectively. The leiognathid fishes continued to dominate at all stations, except at Station 11 where the threadfin sea catfish (Arius arius, 6.5-20.5cm) alone $\left(1590 \mathrm{ha}^{-1}\right)$ outnumbered all other species. An interesting record is the striped eel catfish (Plotosus lineatus); juveniles (8.9-12.5cm) were abundantly caught from stations 11 to 12 . They are the only eel catfish found in coral reefs, but are also known to be found in estuaries and open waters. According to Fishbase's notes [32], juveniles often form dense ball-shaped schools of about 100 fish, whereas adults (males up to $32 \mathrm{~cm} \mathrm{TL}$ ) are solitary or occur in smaller groups of around 20. Other commerciallyimportant marine species recorded were juveniles of the Indian threadfish (Alectis indicus, $19 \mathrm{~cm}$ ), needlescaled queenfish (Scomberoides tol, 18.2$19.8 \mathrm{~cm}$ ), the torpedo scad (Megalaspis cordyla, 12.8$13.2 \mathrm{~cm}$ ) and orange-spotted snapper (Epinephelus coioides, $11.3 \mathrm{~cm})$. Low numbers and few species of fish were caught at the furthest station near the tidal barrage where the salinity was the lowest (12.5 ppt). The fish included the white sardine (Escualosa thoracata), Bloch's gizzard shad (Nematolosa nasus), greyfin croaker (Pennahia anea), green rough-backed pufferfish (Lagocephalus lunaris) and deep pugnose ponyfish (Secutor ruconius).

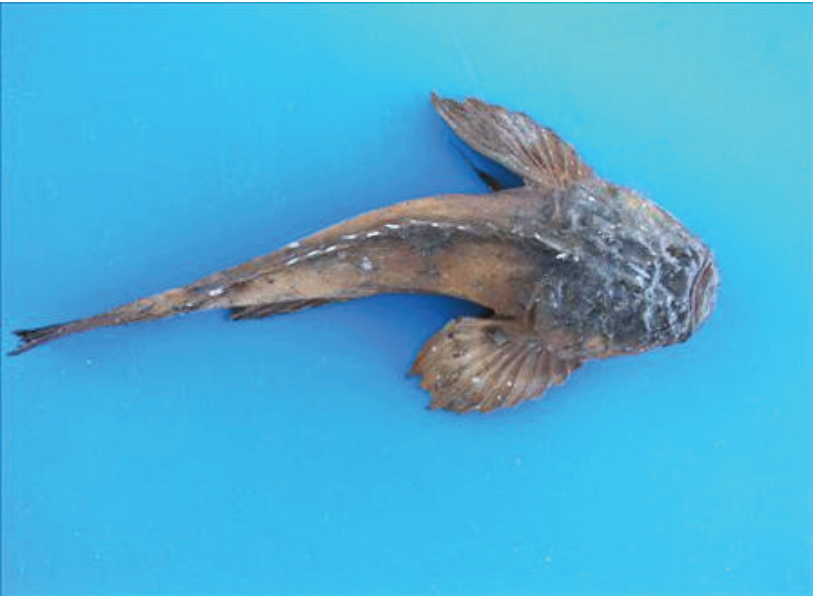

Figure 3. Stonefish, Leptosynanceia asteroblepa (dorsal view, $12.7 \mathrm{~cm} \mathrm{SL}$ )

Invertebrate fauna were poor; the invertebrates sampled from only stations 11-13 were the mangrove mudcrab (Scylla sp.), porter crab (Neodorippe), hermit crab and two prawn species (Metapenaeus brevicornis, M. mastersii).

The Semerak estuary had low numbers and abundance of prawn species, as was also the case for Kuantan estuary on the east coast where four species had been reported [25]. In contrast, the number of prawn species reported for Langkawi, Matang, Klang, Sungai Pulai and Sungai Johor mangroves on the west and south coast of the peninsula were 8 [7], 20[11], 9 [19], 15 [22] and 17 [22], respectively.

\section{Semerak lagoon}

Six fish and five invertebrate species were sampled by the beam trawl and gill nets (Table 4). Their catches were low, except for the common ponyfish (Leiognathus equulus) which were captured in quite large numbers by the gill nets. Captured invertebrates not found elsewhere in this study included the horseshoe crab (Carcinoscopius rotundicauda) and a bivalve, Belcher's venus (Tapes belcheri, Figure 4). Another species of common bivalve found was the yellow pitar venus (Pitar citrinus, Figure 5) which was only sampled in the coastal waters at Station 5 . The generally poor numbers of large species of fish in Semerak lagoon is likely due to its isolation from the sea and anthropogenic impacts from extensive aquaculture activities.

\section{Bachok coastal waters}

In the northern half of the surveyed area, the first station (1.5 km offshore) yielded no catch, but station 2 located $3 \mathrm{~km}$ offshore yielded 18 species of fish, the lowest among the northern stations sampled. The fish catch comprised largely of one species of 


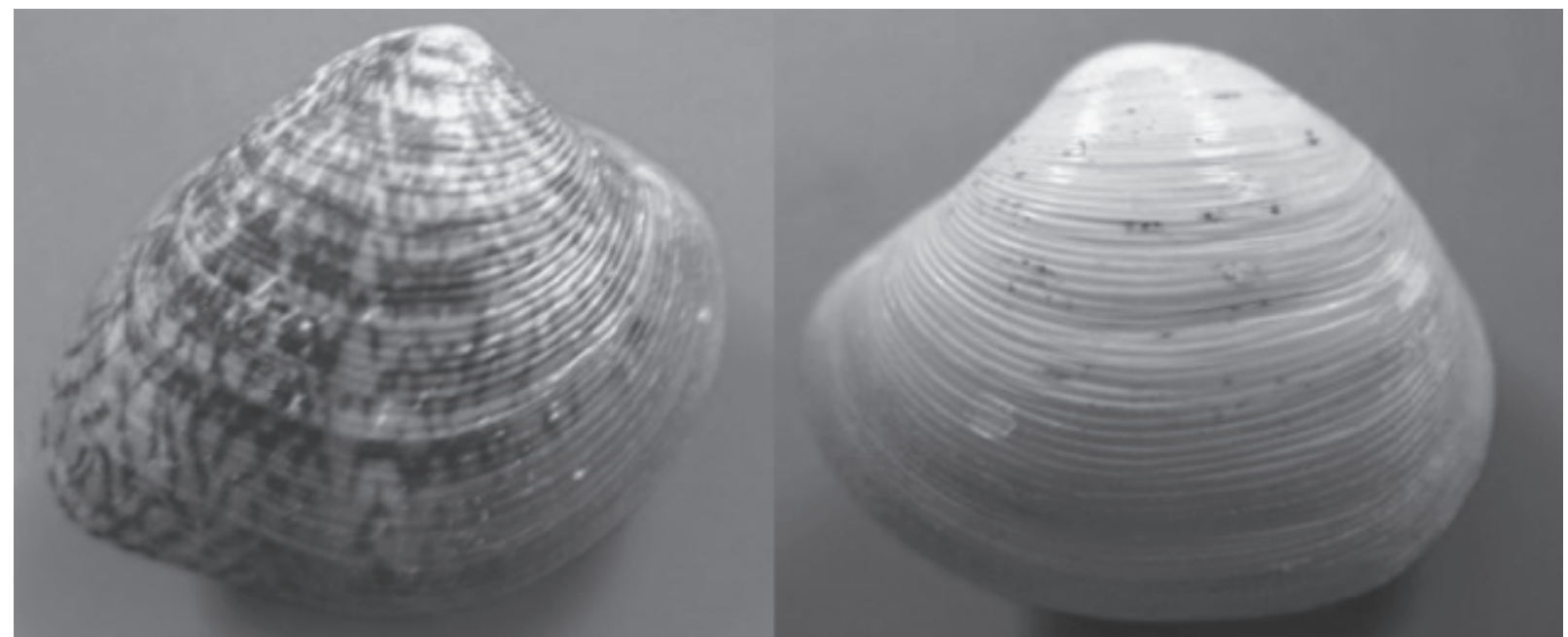

Figure 4. Venerid bivalve - Belcher's venus, Tapes belcheri $(3.7 \mathrm{~cm} \mathrm{TL}, 2.8 \mathrm{~cm} \mathrm{HT})$

Leiognathidae, the slender ponyfish (Equulites elongatus), the sulfur goatfish (Upeneus sulphureus) and twostripe cardinal (Apogon quadrifasciatus) (see Table 3). Nine species of invertebrates were sampled, including young squids (Loligo duvacelli, 1.9$15.5 \mathrm{~cm}$ ) and the flower portunid crab (Portunus pelagicus, $1.6-11.9 \mathrm{~cm})$.

South of stations 1 and 2, the coastal waters between Kg. S. Dua and Kg. Tekah Dua were heavily fished by gillnet fishers. These waters were therefore avoided by our trawl boat. Stations 3, 4 and 5 located further south yielded the highest number of species $(40,32,38)$ among the 14 stations sampled by the trawl net. The leiognathids again dominated these waters, the main identified species being the shortnose ponyfish (Leiognathus brevirostris), whipfin ponyfish (Equulites leuciscus), deep pugnose ponyfish and the slender ponyfish. The highest number of invertebrate species was also recorded from these waters which were dominated by squids and juvenile flower crabs. Other interesting species recorded from here and nowhere else from this study included the three-spot swimming crab (Portunus sanguinolentus, Figure 6), the oriental flathead lobster (Thenus orientalis) and the smalleyed squillid mantis shrimp (Miyakea nepa).

From Tok Bali jetty to the south, the coastal waters had the poorest number of species sampled (4-8 species). Overall, the southern section had a total of only 18 species sampled as compared to the northern section with 83 species. The only invertebrate sampled were two species of squid. Nevertheless, the largest single mass of fish sampled in this study came from station 8 , comprising more than $12,000 \mathrm{ha}^{-1}$ of juvenile splendid ponyfish, (Eubleekeria splendens,
Figure 5. Pitar venus shell, Pita citrinus ( $3 \mathrm{~cm} \mathrm{TL}$, $3.2 \mathrm{~cm} \mathrm{HT}$ )

7.5-10.7mm). another leiognathid species, the toothed pony, (Gazza minuta, 506ha ${ }^{-1}$ ) and the sulphur goatfish $\left(813 \mathrm{ha}^{-1}\right)$ occurred in abundance at station 7 .

Although no coral reefs have been reported in Bachok waters, the occurrence of three reefassociated fish species is interesting. These were the red cornetfish (Fistularia petimba), Peters' monocle bream (Scolopsis affinis) and purple-spotted bigeye (Priacanthus tayenus); all three were sampled from the northern coastal waters.

\section{Rekang estuary and surf zone}

The most surprising and interesting catch from the small river was a large milkfish (Chanos chanos, 29 $\mathrm{cm}, 500 \mathrm{~g}$; Figure 7) caught by cast net. According to the villagers in $\mathrm{Kg}$. Rekang, large numbers of even larger milkfish come into the Rekang estuary during the flood or northeast monsoon season from December-January. Fishase [32] reported that milkfish can grow up to a very large size of $124 \mathrm{~cm}$ $(14 \mathrm{~kg})$. Milkfish has never been reported by research surveys on the west coast or from commercial fish landings. A few greenback mullets (Liza subviridis) were also caught in the river which had a salinity of almost 0 ppt.

Just outside the river mouth which was blocked up by shifting sand, nine species of fish and the colorful flower moon crab (Matuta planipes, Figure 8) were sampled from the surf water by a beach seine (Table 4). The dwarf whipray (Himantura walga) and bluetail mullet (Valamugil buchanani) were sampled only here. 


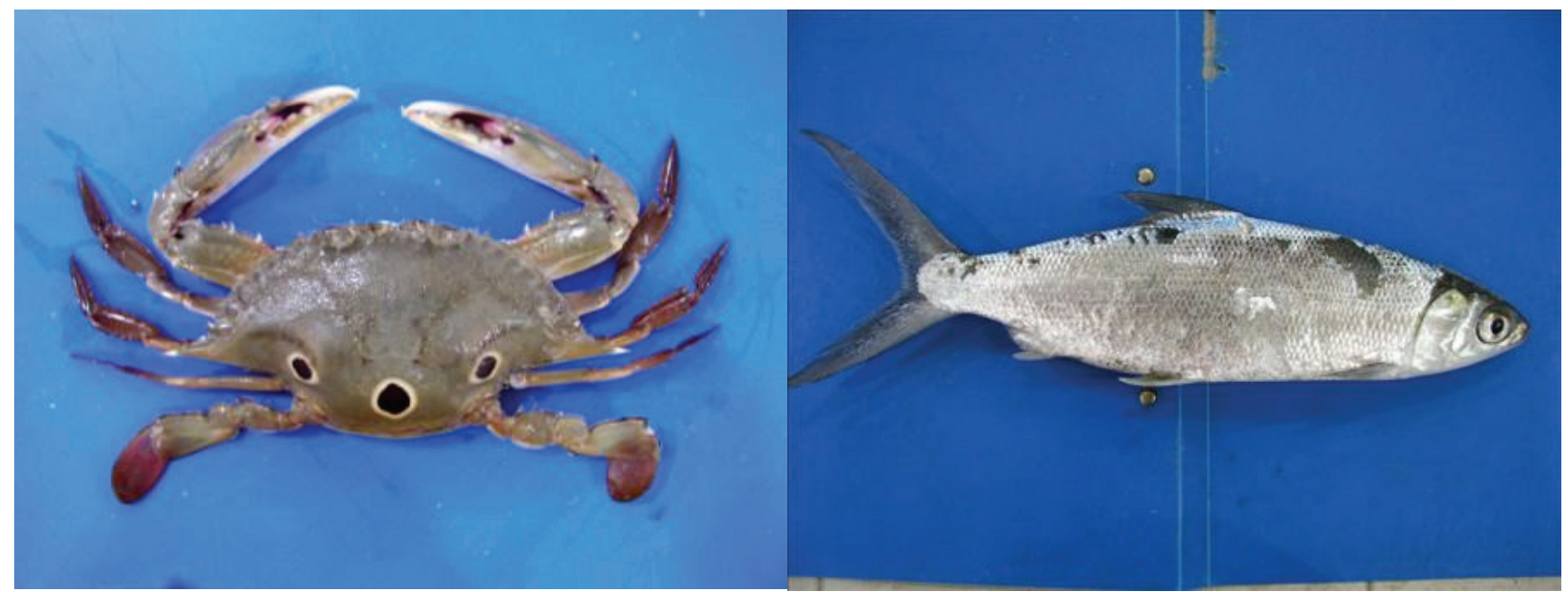

Figure 6. Three-spot swimming crab, Portunus sanguinolentus $(11.5 \mathrm{~cm} \mathrm{CW})$.

\section{Standing stock biomass Semerak estuary}

Inside the channelized Semerak River, the total standing stock biomass estimated for the 5 stations, ranged from 0.63 to $47.62 \mathrm{~kg} \mathrm{ha}^{-1}$, with a mean of $17.79 \pm 16.79$ (Table 5). While leiognathids were largely important by numbers, the larger fish from the Ariidae, Plotosidae, Lutjanidae and Sphrynaenidae contributed substantially to the standing stock biomass.

Despite the impoundment and channelization impact, the Semerak estuary had a standing stock biomass comparable to that of Sementa Kecil River in Selangor $\left(\right.$ mean $\left.=21.4 \mathrm{~kg} \mathrm{ha}^{-1}\right)$ [19] and Pulai estuary in Johor $\left(10.41-46.23 \mathrm{~kg} \mathrm{ha}^{-1}\right)$ [22], but lower than six Matang estuaries in Perak which ranged from 43.09 - $116.12 \mathrm{~kg}$ ha-1) [34].

\section{Bachok coastal waters}

The standing stock biomass of fish and invertebrates from off Kuala Rekang (station 1) to Tok Bali jetty ranged from 0 to $26.27 \mathrm{~kg} \mathrm{ha}^{-1}$, with mean of $12.00 \pm$ 10.05 while that of the southern coast from Tok Bali Jetty to off $\mathrm{Kg}$. Dalam Rhu (station 9) ranged from 0.36 to $355.93 \mathrm{~kg} \mathrm{ha}^{-1}$ with a mean of $94.36 \pm 174.48$ (Table 5). The largest standing stocks in the northern and southern waters were at station 3 (off Kuala Kandis) and at station 8 (off Kuala Semerak), attributable to the large concentrations of leiognathids.

Compared to the nearshore waters of Klang Strait which had close values of H' $(=2.78)$ and J' $(=0.68)$ but a total mean biomass of only $7.61 \mathrm{~kg} \mathrm{ha}^{-1}$ [19], Bachok's inshore waters had a generally higher standing stock biomass. The monthly fish stock biomass of Matang coastal waters, with monthly H'
Figure 7. Milkfish, Chanos chanos (29 cm SL).

that ranged from $1.95-3.05$ and J' from $0.53-0.82$, ranged from $0.75-2.72 \mathrm{~kg} \mathrm{ha}^{-1}$ [35] only, indicating that both Perak and Selangor coastal waters were heavily overfished.

\section{Between estuarine and coastal waters}

The community similarity indices between the northern coastal and southern coastal waters with Semerak estuary were 0.214 and 0.132 respectively. These results indicate low resemblance between the coastal and estuarine communities. Thus, there is little connectivity or contribution of mangrove species to coastal fisheries production. In areas where mangrove forests are more significant, as for instance Matang, fish production contribution could be more than $50 \%$ [12]. Among the fish families, the Leiognathidae is probably the most connected between the coastal and disturbed estuarine waters of Bachok demonstrating their adaptability to human disturbance.

\section{Leiognathid distribution}

The entire coastal waters of Bachok were occupied by largely Leiognathidae, with at least eight species identified. Leiognathid predominance in Bachok waters resembles the situation along Pahang's northern coast where leiognathids also dominated the fish community. In both Bachok and north Pahang, the predominant species were Eubleekeria splendens and Secutor rucornius, but in Pahang, Gazza minuta was also abundant [25]. In Bachok, Equulites elongatus was common in coastal waters, while Leiognathus brevirostris and $L$. equulas were common and abundant in Semerak estuary.

In contrast, leiognathids do not dominate coastal waters in the Straits of Malacca by sheer numbers as they did in the South China Sea. Leiognathus brevirostris, L. daura and Secutor insidiator were the 
Table 5. Main taxa and estimates of total stock biomass by station in Bachok coastal waters and Semerak Estuary, Kelantan (15-17 June, 2008).

\begin{tabular}{|c|c|c|c|c|c|}
\hline Area & Date & Station & Trawl & $\begin{array}{c}\text { Biomass } \\
\text { (kg/ha) }\end{array}$ & Main taxa \\
\hline \multicolumn{6}{|l|}{ Northern } \\
\hline \multirow[t]{7}{*}{ Coast } & 16-Jun & 1 & 1 & 0.00 & No catch \\
\hline & 16-Jun & 2 & 2 & 5.70 & Leiognathidae, Loligo,Pseudorhombus, Nemipterus \\
\hline & 16-Jun & 3 & 3 & 26.27 & Leiognathidae, Dasyatidae, Sciaenidae, Ariidae, \\
\hline & 16-Jun & 4 & 4 & 16.05 & Leiognathidae, Sepiidae, Pseudorhombus \\
\hline & 16-Jun & 5 & 5 & 11.97 & Leiognathidae, Loligo \\
\hline & mean & & & 12.00 & \\
\hline & SD & & & 10.05 & \\
\hline \multicolumn{6}{|l|}{ Southern } \\
\hline \multirow[t]{6}{*}{ Coast } & 15-Jun & 6 & 4 & 0.36 & Loligo \\
\hline & 15-Jun & 7 & 1 & 6.51 & Loligo, Leiognathidae \\
\hline & 15-Jun & 8 & 2 & 355.93 & Leiognathidae, \\
\hline & 15-Jun & 9 & 3 & 14.65 & Leiognathidae, \\
\hline & mean & & & 94.36 & \\
\hline & $\mathrm{SD}$ & & & 174.48 & \\
\hline \multicolumn{6}{|l|}{ Semerak } \\
\hline \multirow[t]{8}{*}{ Estuary } & 17-Jun & 15 & 6 & 19.27 & Leiognathidae, Lutjanidae, Pampus, Platycephalidae \\
\hline & 17-Jun & 10 & 1 & 19.92 & Leiognathidae, Lutjanidae, Ariidae \\
\hline & 17-Jun & 11 & 2 & 47.62 & $\begin{array}{l}\text { Ariidae, Leiognathidae, Tetraodonidae, Sphrynaenidae, } \\
\text { Plotosidae }\end{array}$ \\
\hline & 17-Jun & 12 & 3 & 16.25 & Ariidae, Leiognathidae, \\
\hline & 17-Jun & 13 & 4 & 3.08 & Leiognathidae \\
\hline & 17-Jun & 14 & 5 & 0.63 & Sciaenidae, Clupeidae \\
\hline & mean & & & 17.79 & \\
\hline & $\mathrm{SD}$ & & & 16.79 & \\
\hline
\end{tabular}

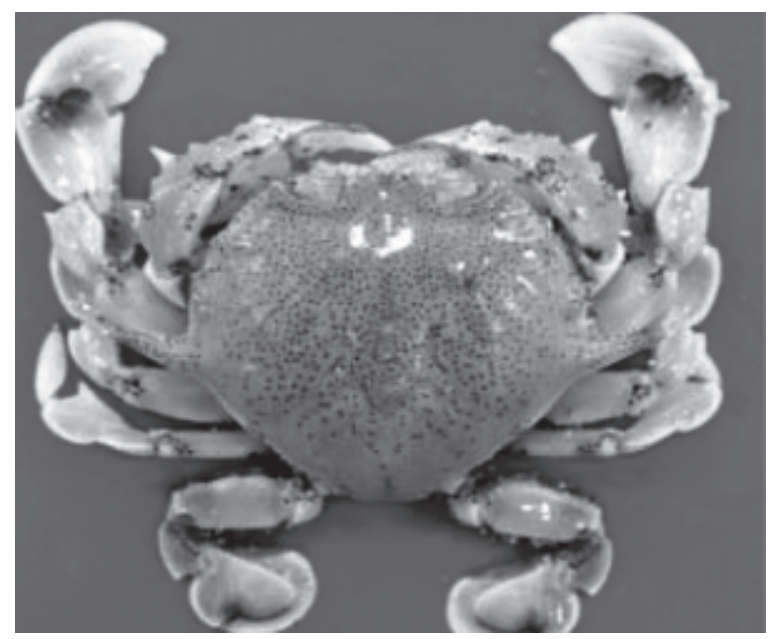

Figure 8. Flower moon crab, Matuta planipes $(3.5$ $\mathrm{cm}$ CW).

dominant leiognathids in Klang Strait but their numbers constituted no more than $10 \%$ [19], while in Matang estuaries, the most recent study indicated four species, the most widespread being $L$. brevirostris [34]. This species and S. rucornius were the common leiognathids in Matang nearshore waters [35]. In northeastern Langkawi waters, six species of leiognathids have been recorded of which the most common and abundant were also L. brevirostris and S. rucornius [7].

Leiognathids also called slipmouths show very interesting adaptations of their mouth structure which could protrude down to pick up benthic worms, foraminiferans, small fish, crustaceans and bivalves from soft bottoms, or protrude up to feed on pelagic organisms like zooplankton [32]. These adaptations suggest niche separation of often co-occurring species in similar habitats or a geographical region. This appears to be the case in the present study where eight identified species were found together in Bachok waters.

The leiognathids appear to be spatially separated as evidenced below:

- Equulites elongates was only distributed on the northern section of the coast, while Secutor insidiator was mainly found on the southern coast. 
- The congener, S. rucornius, was however found only in the northern coast but was clearly also distributed inside the estuary.

- The distribution of Eubleekeria splendens was mainly in the southern coast but extended deeply into the estuary.

- Leiognathus equulus was only sampled inside the estuary.

- Leiognathus brevirostris was particularly abundant at station 3, not observed in the southern coast, but also distributed inside the estuary.

- Equulites leuciscus was distributed from station 3 to station 5 , and neither observed in the estuary or southern coast.

Niche separation of co-occurring species could be further verified by diet analysis as well as fish activity or behavioural studies.

\section{CONCLUSIONS}

The modified Semerak estuary shows a partiallymixed estuary that is visited by at least 59 marine and euryhaline species, including 47 fish species. The fish include economically-important species of leiognathids, lutjanids, catfishes, baraccudas, pomfrets and squids. Bachok's nearshore waters provide habitat, feeding or nursery space for at least 71 fish and 22 invertebrate species. Young leiognathids, mullids, cephalopods and portunid crabs were dominant. The former with eight species displayed spatial distribution from coastal to estuarine waters. Bachok's coastal fish diversity is generally high, with larger standing stock biomass than similar habitats on the west coast of peninsular Malaysia. It would be of interest to further monitor the fish assemblage in the channelized river and to compare it with the natural segment of the river to assess the impacts of the river modification.

\section{ACKNOWLEDGEMENTS}

We are grateful to the University of Malaya for providing PJP research grant FS301/2008A and to the Institute of Ocean and Earth Sciences for providing logistical and other research support. We thank Mr. Muhammad Ai'Amin for managing the expedition including organizing the fishing boat and field transport.

\section{REFERENCES}

1. Chong, V.C. (2007). Mangrove - fisheries linkages - the Malaysian perspective. Bulletin of Marine Science 80(3): 755-772.
2. Ronnback, P., Macia, A., Almqvist, G., Schultz, L. and Troell, M. (2002). Do penaeid shrimps have a preference for mangrove habitats/ Distribution pattern analysis on Inhaca Island, Mozambique. Estuarine Coastal and Shelf Science 55: 427- 436.

3. Mumby P.J. et al. (2004). Mangroves enhance the biomass of coral reef fish communities in the Caribbean. Nature 427:533-536.

4. Manson, F.J., Loneragan, N.R., Harch, B.D., Skilleter, G.A. and Williams, L. (2005). A broad-scale analysis of links between coastal fisheries production and mangrove extent: A case-study for northeastern Australia. Fisheries Research 74: 69-85.

5. Blaber, S.J.M. (2007). Mangroves and fishes: issues of diversity, dependence, and dogma. Bulletin of Marine Sciences 80(3): 457-472.

6. Aburto-Oropeza, O., Ezcurra, E., Danemann, G., Valdez, V., Murray, J. and Sala, E. (2008). Mangroves in the Gulf of California increase fishery yields. PNAS 105(30): 10456-10459.

7. Chong, V.C., Ng, Y.P. Ng, Hairi, B.J., Ooi, A.L., Chew, L.L., Amirah, M., and Affendy, B.N. (2005). Update of the fishes of mangrove and coastal waters of northeastern Langkawi. Malaysian Journal of Science 24: 167-184.

8. Norma-Rashid, N. \& Khaironizam, M.Z. (2005). Some biological aspects of mudskippers (Gobiidae Oxudercinae) from Langkawi Island. Malaysian Journal of Science 24: 139-144.

9. Khoo, K.H. (1990). The mangrove fisheries in Matang, Perak and Merbok, Kedah. In (B.H.R. Othman, compiler) Report of ASEAN Australia Cooperative Program on Marine Science Coastal Living Resources Project, Phase I, Faculty of Sciences, UKM, Bangi, Malaysia, pp. 115-144.

10. Hanamura, Y., Ryon Siow, Chee, P.E. (2008). Reproductive biology and seasonality of the Indo-Australasian mysid Mesopodopsis orientalis (Crustacea: Mysida) in a tropical mangrove estuary, Malaysia. Estuarine, Coastal and Shelf Science 77: 467- 474.

11. Low, C.B., Chong, V.C., Hayase, S. and Lim, L.H.S. (1999). Prawn production of Matang and Dinding mangroves: species distribution and seasonal recruitment. In: Productivity and Sustainable Utilization of Brackish Water Mangrove Ecosystems, Proceedings $4^{\text {th }}$ Seminar on Results for 1997/98 Research Projects, eds. Kiso, K. \& P.S. Choo, JIRCAS, Tsukuba, Japan, pp. 89-101.

12. Sasekumar, A., Chong, V.C., Lim, K.H. and Singh, H.R. (1994). The fish community of Matang mangrove waters. In: Proceedings, 
Third-ASEAN-Australia Symposium on Living Coastal Resources, Vol. 2: Research Papers, eds. Sudara S., C.R. Wilkinson, L.M. Chou, Chulalongkorn University, Bangkok, Thailand, pp. 457-464.

13. Hayase, S., Ichikawa, T. \& Tanaka, K. (1999). Preliminary report on stable isotope ration analysis for samples from Matang mangrove brackish water ecosystem. Japan Agriculture Research Quarterly 33:215-221.

14. Chong,V.C., Low, C.B. \& Ichikawa, T. (2001). Contribution of mangrove detritus to juvenile prawn nutrition: a dual stable isotope study in a Malaysian mangrove forest. Marine Biology 138: 77-86.

15. Ahmad Adnan, N., Loneragan, N.R. and R.M. Connolly (2002). Variability of, and the influence of environmental factors on, the recruitment of postlarval and juvenile Penaeus merguiensis in the Matang mangroves of Malaysia. Marine Biology 141: 241-251.

16. Kiso, K. and Mahyam, M.I. (2003). Distribution and feeding habits of juvenile and young John's snapper Lutjanus johnii. Fisheries Science 69: 563-568.

17. Chong, V.C. \& Sasekumar, A. (1981). Food and feeding habitaas of the white prawn Penaeus merguiensis. Mar. Ecol. Prog. Ser. 5: 185-191.

18. Rodelli, M.R., Gearing, J.N., Gearing, P.J., Marshall, N. and Sasekumar, A., (1981). Stable isotopes ratio as a tracer of mangrove carbon in Malaysian ecosystems. Oecologia 61: 326-333.

19. Chong, V.C., A. Sasekumar, M.U.C. Leh and Cruz, R.D. (1990). The fish and prawn communities of a Malaysian mangrove system, with comparisons to adjacent mud flats and inshore waters. Estuarine, Coastal and Shelf Science 31:703-723.

20. Newell, R.I.E., Marshall, N., Sasekumar, A. and Chong,V.C. (1995). Relative importance of benthic microalgae, phytoplankton and mangroves as sources of nutrition for penaeid prawns and other coastal invertebrates from Malaysia. Marine Biology 123: 595-606.

21. Sarpedonti, V. \& Chong, V.C., (2008). Abundance and distribution of Stolephorus baganensis Hardenberg 1933 and Thyrssa kammalensis (Bleeker 1849) larvae in relation to ontogeny and environmental factors in a Malaysian estuary. Tropical Zoology 21(2): 195208.

22. Chong, V.C. \& Sasekumar, A. (2002). Fish communities and fisheries of Sungai Johor and Sungai Pulai estuaries (Johor, Malaysia). Malayan Nature Journal 56(2): 279-302.
23. Wong, S.L (2004). Matang Mangroves- $A$ Century of Sustainable Management. Forestry Department Malaysia \& State Forestry Department of Perak.

24. Annual Fisheries Statistics (2005). Volume 1, Department of Fisheries Malaysia, Ministry of Agriculture and Agrobased Industries, Putrajaya, Malaysia.

25. Chong, V.C. (2001). Marine and fisheries resources. In: Shoreline Management Plan of the Coastline from Kuala Sg. Pahang to the State Boundary of Pahang/Terengganu: Baseline Report, Vol. 1, Chapter 4. Drainage and Irrigation Department, Malaysia.

26. Munro, I.S.R. (1955). The Marine and Freshwater Fishes of Ceylon. Department of External Affairs, Canberra, Australia.

27. Fishcher, W. and P.J.P. Whitehead (eds.). (1974). FAO Species Identification Sheets for Fisheries Purposes. Eastern Indian Ocean and Western Central Pacific, Vol. 1-4, FAO, Rome.

28. De Bruin, G.H.P., Russel, B.C. \& Bogusch, A. (1994). The marine fishery resources of Sri Lanka. FAO Species Scientific Field Guide for Fishery Purposes, FAO, Rome.

29. Mohsin, A.K.M. and Ambak, M.A. (1996). Marine Fishes and Fisheries of Malaysia and Neighbouring Countries. Universiti Pertanian Press, Serdang, Malaysia.

30. Kent, E.C. and Volker, H.N. (1998a). The Living Marine Resources of the Western Central Pacific, Vol.1 Seaweeds, corals, bivalves and gastropods. FAO, Rome.

31. Kent, E.C. and Volker, H.N. (1998b). The Living Marine Resources of the Western Central Pacific, Vol.2 Cephalopods, crustaceans, holothurians and sharks. FAO, Rome.

32. Fishbase World Wide Web electronic publication, www.fishbase.org.

33. Sparre, P. \& Venema, S.C. (1992). Introduction to Tropical Fish Stock Assessment. Part 1 Manual. FAO Fisheries Technical Paper 306/1 (Rev. 1). DANIDA/FAO, Rome.

34. Amy Then, Y.H. (2008). The structure and trophodynamics of the fish community in estuaries of Matang mangrove forest reserve, peninsular Malaysia. M.Sc thesis submitted to the Institute of Biological Sciences, Faculty of Science, University of Malaya, Kuala Lumpur.

35. Mohammad Yazid bin Abdullah (2006). Distribution and abundance of fish in the coastal waters of Matang mangrove, Kuala Sepetang, Perak. B.Sc Honours thesis, Ecology \& Biodiversity Programme, Institute of Biological Sciences, University of Malaya, Kuala Lumpur (in Malay). 